\title{
OB CIVIS SERVATOS: OTÁVIO AUGUSTO COMO O SALVADOR DOS CIDADÃOS ROMANOS NAS MOEDAS (30 AEC - 14 EC)
}

\author{
OB CIVIS SERVATOS: a numismatic analysis of Octavius Augustus as the savior of the \\ roman people (30BCE - $14 \mathrm{CE})$
}

\section{Carlos Eduardo da Costa Campos*}

\begin{abstract}
Resumo: É possível afirmar que as moedas são objetos utilizados desde a Antiguidade e que circularam por várias regiões do mundo. Assim, são fontes valiosas de investigação em razão da cunhagem estar ligada a algum tipo de autoridade, contexto econômico e social. O consumo (uso) dessas mesmas moedas normalmente envolve todos os níveis da sociedade e podem ser rastreados cientificamente. Desse modo, nesse texto buscamos analisar a iconografia augustana sobre a restauração da ordem social, entre 30 AEC e 14 EC, por meio da numismática para compreender questões inerentes à dinâmica cultural do governo de Otávio Augusto.
\end{abstract}

\begin{abstract}
Coins are objects used since Antiquity and have circulated throughout several regions worldwide. Thus, they are valuable sources of research, as coinage is always linked to some type of authority and economic or social context. The consumption (use) of these currencies usually involves all levels of society and can be traced scientifically. Thus, this study seeks to analyze the Augustan iconography concerning the restoration of the social order between $30 \mathrm{BCE}$ and $14 \mathrm{CE}$, through numismatics in order to understand issues inherent to the cultural dynamics of Augustus' government.
\end{abstract}

\section{Introdução}

Entre o período de 30 AEC e 14 EC, observamos evidências discursivas imagéticas de Otávio Augusto como restaurador da ordem social romano. Temos como pressuposto que esse recurso iconográfico numismático integrou uma das diversas medidas que lhe permitiu comunicar e se consolidar no poder. Christian Meier (1993, p. 67) salienta que esta ação de buscar visibilidade social, jogar com as demandas sociais e toda sensibilidade política de Otávio Augusto e seus apoiadores foram importantes para o sucesso que ele deteve em Roma. Assim, concordamos que habilidades como a inteligência, paciência, delicadeza, uma forte sensação de poder, perspicácia, astúcia e muitas outras características também foram cruciais para a edificação de um princeps carismático. Nesse campo, a arte e a imagem de Augusto assumiram funções centrais na comunicação do poder. Logo, para o êxito do princeps, ele precisava ser capaz de desempenhar um papel específico e demonstrar que estava fazendo isso com muita abnegação.

Houve um projeto político que compreendemos não como um elemento predestinado ao sucesso, mas como um empreendimento político que apresentou tentativas, erros, adaptações e êxitos. Na própria Res Gestae Divi Augusti $(\operatorname{RGD} A)$, percebemos uma intencionalidade em sua

\footnotetext{
* Prof. Adjunto do curso de História da Universidade Federal de Mato Grosso do Sul. Coordenador do grupo de pesquisa: Espaço Interdisciplinar de Estudos da Antiguidade - ATRIVM / UFMS e doutorando em Letras Clássicas pelo PPGLC/UFRJ. Brasil. Email: kaduygniz@gmail.com
} 
construção discursiva para expressar os poderes de Otávio Augusto como menos exacerbados para a época e uma ênfase nos seus feitos como essenciais também para as gerações posteriores. As ações de Otávio refletem um compromisso no tocante à manutenção da paz social. Logo, na linguagem política augustana, fazia toda diferença ele ser a pessoa que aparece como o primeiro cidadão (princeps) $)^{1}$ ao invés de um tirano ou monarca. Na visão de Christian Meier (1993, p. 68), o Principado foi formado por uma relação dialética entre o desenvolvimento de um papel e as expectativas a que esse papel deveria corresponder socialmente. A posição do princeps era extremamente delicada, e foi somente com a sensibilidade política para o contexto da época que Augusto conseguiu lidar com o fato de que, mesmo em condições alteradas após as guerras civis, as alternativas ao sistema existente precisariam ser ligadas à tradição, que era completamente republicana no imaginário social romano (Baczko, 1985, p. 311).

Desse modo, pensamentos calcados nos conceitos de rupturas e continuidades podem nos enganar, quando queremos ver apenas por um prisma, assim gerando ilusões óticas em nossas análises históricas. Devemos observar que a trajetória de uma sociedade ocorre em meio a uma gama de processos sociais, que envolvem junções e disjunções políticas, econômicas, culturais e religiosas de forma concomitante. Em nossa perspectiva, as concepções político-culturais e as instituições que existiam no período Republicano e que foram apropriadas por Otávio Augusto no Principado (27 AEC - 14 EC) passaram, em alguns casos, por um processo de ressignificação social, assim preservando elementos do passado e agregando novos sentidos para as demandas que naquele período emergiam em Roma. Dessa forma, é necessário efetuar uma distinção entre as continuidades e rupturas aparentes daquelas que foram reais. Ou seja, analisar minuciosamente o período de transição que foi a era de Augusto com atenção nas modificações e permanências que ocorreram em contextos geográficos e sociais específicos.

Endossamos nossas assertivas com as análises de Fábio Faversani (2013, p. 110), pois, para o referido historiador, não houve uma profunda ruptura ente a República e o Império, demarcada a emergência de Augusto no poder, como costumamos verificar cronologicamente. O pesquisador propõe uma reflexão sobre a República e sobre o Império: “[...] como tendo múltiplas fronteiras, conforme se pense experiências históricas diversas. Ainda mais, propomos pensar a divisão entre República e Império não como uma ruptura, mas como uma fronteira” (Faversani, 2013, p. 110). Nesse sentido, para Faversani, o conceito de fronteira propicia perceber a ligação e a separação existentes entre aquilo que denominou de várias "Repúblicas" e "Impérios".

Vale ressaltar que o regime dos césares fundado por Otávio Augusto, por exemplo, era muito diferente das monarquias com as quais estamos mais familiarizados, ou seja, os imperadores da Antiguidade Tardia, bem como da realeza medieval e/ou moderna, pela ausência de uma verdadeira hereditariedade familiar do trono, como destacado por Jean Béranger (1975, p. 137-8) e Paul Veyne (2009, p. 1). Com efeito, o novo sistema não representava uma ruptura com a antiga ordem social. Por isso, o cargo de princeps romano era de alto risco no Principado. Afinal, o governante ocupava o comando geral não como proprietário, mas como mandatário da coletividade e por esta era encarregado de dirigir as demandas da República. Veyne ressalta que a lógica da coletividade delegando poder ao imperador, não passaria de uma ilusão, de uma construção, mas um imperador necessitava desse discurso para ser legítimo no poder. Ou seja, a opinião pública importava para assegurar a governabilidade.

1 Princeps: primeiro entre os cidadãos, um antigo título republicano que foi apropriado por Augusto para denotar o seu comando e poder (CAMPOS, 2017, p. 387). 
Desse modo, o governo de Augusto era construído não como uma ruptura ou mera continuidade, mas como uma nova forma adaptada de exercício do poder, que se valia de uma imbricação entre a inovação e o antigo. Sendo assim, havia a delegação do poder, ou seja, uma missão que foi confiada a um cidadão romano supostamente escolhido e aceito pelo povo romano. A sucessão dos césares, em tese, seria uma "cadeia perpétua de delegações", como foi salientado por Veyne (2009, p. 1) e também abordado por Béranger (1975, p. 137-8). Para que o legado de um princeps fosse mantido, a sucessão era um elemento imprescindível, o que expressa o sucesso entre os JúlioClaudianos. Logo, para ambos autores, o imperator / princeps não é um rei, pois o seu cargo é explicitamente resultado de uma investidura que deveria ser aceita pelas instituições romanas.

Em linhas gerais, percebemos que as ações de Otávio Augusto eram aceitas na medida em que ele mantinha uma aparência sobre o seu comportamento e respeito aos valores tradicionais, tornando-os de conhecimento público, assim como se absteve de ofender a memória dos cidadãos mais antigos de Roma. Além disso, também pontuamos que o Principado de Otávio Augusto se configura como uma fase de transição, na qual notamos imbricações político-culturais em que microrrupturas ocorrem não ao mesmo tempo, mas em um longo período. Assim, é essencial levarmos em consideração os níveis que estamos analisando. Afinal, em um recorte temporal encontramos fissuras, inovações e continuidades, pois algumas mutações podem ocorrer de uma forma mais lenta que outras e havendo utilização das tradições da sociedade. Em pesquisas que envolvem um período de transição, como o Principado de Augusto, devemos ter cuidado com relações binárias de oposição e, assim, investir em categorias reflexivas que nos possibilitem ter uma visão conjuntural da sociedade. Em nossa concepção, duas chaves políticas eram importantes para que Augusto garantisse a sua governabilidade: o respeito à tradição e o prestígio político-social.

Baseados nas reflexões acima, postulamos que o poder institucionalizado ou em vias de institucionalização necessita da formulação de múltiplos dispositivos culturais para a sua integração social e preservação ao longo dos tempos. Desse modo, a nova ordem de Augusto, como detentor da potestas ${ }^{2}$, tinha o intuito de assegurar a governabilidade por meio de medidas que viessem incutir a sua aceitação social como legítimo líder político. Para isso, Augusto também elaborou um novo repertório carregado de símbolos na literatura clássica, porém, em diversas outras formas de suportes também, as quais refletiam a modificação cultural que os romanos vivenciavam em seu governo. Andrew Wallace-Hadrill, Augustan Rome (2012) e Paul Zanker, Augusto e o Poder das Imagens (1992) argumentam que o uso de imagens promovidas por Augusto foi uma constante durante o seu regime. Essa prática emergiu como uma característica central da sua autocracia, no sentido de monopolizar grande parte dos símbolos de autoridade romana. Os autores evidenciam que essas imagens desvelam o seu projeto de legitimação no poder naquele período.

Mediante o exposto, percebemos que o estudo numismático nos possibilita entender as ações iconográficas dos dirigentes políticos de Roma, bem como atestam eventos da História Militar e Política da Antiguidade em, pelo menos, dois aspectos que consideramos importantes. Primeiro, elas próprias são consequências materiais das decisões políticas que foram emitidas por parte das cidades, impérios e outros tipos de comunidades. Afinal, as emissões não acontecem por um simples acidente. Em segundo lugar, as moedas e suas imagens podem fornecer informações sobre eventos históricos, das práticas culturais e de elementos identitários. Um procedimento que

\footnotetext{
2 Compreendemos a potestas como um poder institucional que era legado aos magistrados em suas eleições ou ao pater familias no âmbito doméstico, enquanto exercessem tal atividade social. Nesse caso, o portador pode empregar a coercitio como uma forma de punição ou correção contra um infrator, como modo de sanar um problema que naquele contexto foi gerado pelo punido (CAMPOS, 2017, p. 387).
} 
tomamos para construir nosso corpus documental foi o estabelecimento de um repertório de moedas, o qual empregamos em nossa pesquisa. Para tanto, recorremos às moedas que foram sistematizadas pelo catálogo C. H. V. Sutherland e R. A. G. Carson, em The Roman Imperial Coinage, em seus 10 volumes, entre os anos de 1923-94.

Para empregarmos esse eixo de reflexão iconográfico necessitamos recorrer ao uso de um crítico aparato metodológico que permita maior embasamento e fundamentação de nosso horizonte de pensamento sobre os elementos imagéticos. Como a arqueóloga Carolina Kesser Barcellos Dias (2009, p. 38 - 40) ressalta: “[...] a imagem não é simples ilustração do discurso oral ou escrito, nem uma reprodução fotográfica do real, ela é uma construção [...]”. Endossamos os apontamentos da autora, com uma de suas matrizes de análise, isto é, Jean Pierre Vernant (1984). O referido pesquisador frisa que a imagem é uma cultura flexível, a qual formula uma linguagem e que detém arbitrariedades e intencionalidades.

Ao pensarmos a imagem como uma construção, devemos perceber que ela é formulada sistematicamente e, com o apoio da análise semiótica, observamos a lógica contida na elaboração de cada imagem e no seu conjunto. Afinal, convergimos com François Lissarrague (1990), Claude Bérard (1983) e Vagner Carvalheiro Porto (2007) quando evidenciam que toda imagem contém um repertório de signos e, para conhecermos os seus significados, torna-se necessário observar as unidades mínimas de forma articulada com o todo. Afinal, sabemos que os itens contidos nas imagens formam discursos, os quais detêm significado e profundidade em sua historicidade.

Ademais, complementamos o viés de análises de Lissarrague e Bérard com os estudos da numismata Maria Caccamo Caltabiano (1998, p. 33 - 40). A numismata argumenta que a junção da imagem com a legenda forma um importante emaranhado discursivo vital para a construção de uma análise iconográfica pelo campo numismático. Dessa forma, a imagem possui um valor histórico e social que deve ser explorado em nossas pesquisas.

Há um consenso historiográfico, como vemos em Andrew Wallace-Hadrill (2012, p. VIII) e Karl Galinsky (2012, p. 33), de que a vitória de Otávio Augusto sobre Marco Antônio e Cleópatra VII na Batalha do Ácio, em 31 AEC, e a tomada de Alexandria em 30 AEC, foram eventos muito maiores que simples conquistas sobre dois rivais políticos para Roma. Em nossas análises, esses fatos históricos compõem um conjunto de representações que marcam as mudanças em vários aspectos políticos e socioculturais no mundo romano. Essas medidas tinham como intenção demonstrar a capacidade de Otávio Augusto e suas redes políticas ${ }^{3}$ em defender o mos maiorum ${ }^{4}$ romano, demonstrando que esse grupo foi o único capaz de unir os múltiplos interesses dos povos em torno de si frente aos inimigos.

Seguindo a visão de Hadrill, em Augustan Rome (2012, p. 1), nota-se que Otávio Augusto produziu no mundo romano um sentimento de uma nova ordem social. Isso não significava alterações apenas no cenário político, mas sim um novo sentido naquilo que Roma foi e aquilo que ela viria a ser em seu governo. Sua nova ordem surgiria gradualmente a partir do difícil contexto que a República Romana perpassou ao longo do século I AEC. Para que seu projeto fosse efetivo, era necessário o enraizamento mitológico de uma nova ordem por Otávio Augusto a partir do Ácio, assim convergimos com a linha de Andrew Goldsworthy (2014), A. Wallace-Hadrill (2012), Carsten

\footnotetext{
3 Redes políticas caracterizam o conjunto de ações entre agentes sociais visando determinada finalidade (KNOKE, 1990, p. 10).

40 mos maiorum pode ser compreendido como o conjunto de costumes e valores tradicionais, passados pelos ancestrais, que devem ser mantidos para a manutenção da estabilidade social e identificação do ser romano (BUSTAMANTE, 2006, p. 112).
} 
Horj Lange (2008), Paul Zanker (1987).

Imersos na iconografia augustana, consideramos que as moedas refletem em seu corpo físico o valor de uma medida e a autoridade impressa de quem as emitiu. Por isso, a propagação da efígie de Augusto era o sinal mais latente que podemos observar de demarcação do seu regime em nosso corpus documental. Reiteramos que não tomamos tais medidas de Augusto como inovações. Portanto, as compreendemos como apropriações de práticas já realizadas anteriormente em Roma, que foram acentuadamente aplicadas em seu projeto político. Dessa forma, elencamos o tema de Augusto como Salvador de Roma e de seus cidadãos. Esse repertório analisado possui um total de trinta e sete recorrências de moedas, as quais foram detectadas em nossas leituras sobre o RIC e inseridas em nossa catalogação ${ }^{5}$. Os tipos de suportes em que encontramos esse tema são: as moedas de áureo, com quatro objetos; e as moedas de sestércio, com trinta e três recorrências, todas da Península Itálica. O período de produção seria entre 27 e 01 AEC, momento esse de consolidação do Principado de Augusto.

A primeira moeda analisada (fig. 1) possui o registro 277 no RIC I, em que vemos um áureo com quatro recorrências do objeto, cunhadas provavelmente em 27 AEC. No anverso da moeda encontramos uma efígie de Augusto virada para a direita. Ainda no anverso, é possível encontrar a legenda CAESAR COS VII CIVIBVS SERVATEIS - Cesar Consul pela sétima vez / Por ter salvo os cidadãos (em ablativo absoluto). No reverso, detectamos a Águia com suas asas expostas e em pé. A ave possui sua face virada para a esquerda e segura com suas patas uma coroa de flores. Atrás de suas asas há dois ramos de louro. Como legenda do reverso, encontramos a seguinte inscrição: AVGVSTVS S C (Senatus Consultum) - Para Augusto por decreto do Senado.
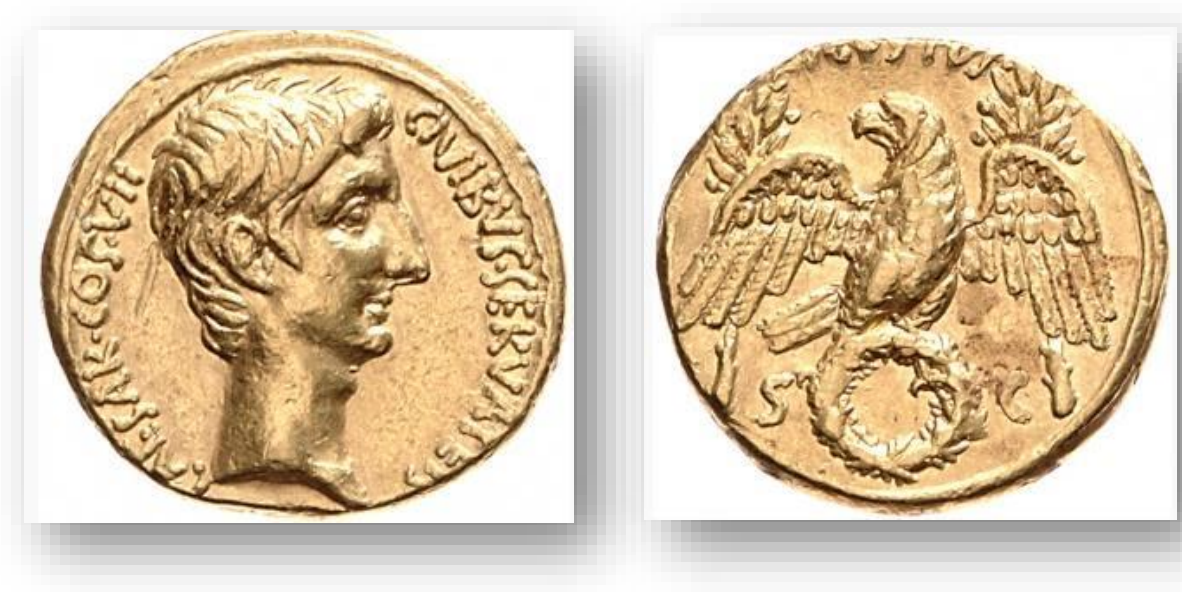

Fig. 1 Tipo de Moeda: Áureo - Ouro; Período: c.a 27 AEC; Região: Península Itálica. Período - VII Consulado de Augusto; CINA, apêndice M 58; Referência: RIC I 277.

Uma variação desse áureo pode ser encontrada no registro 549 do RIC I (fig. 2), em que temos um dupôndio, feito em bronze e com duas recorrências do objeto, as mesmas cunhadas provavelmente em 23 AEC. No anverso da moeda, encontramos uma efígie de Augusto virada para a direita. Ainda no anverso, é possível encontrar a legenda IMP AVGVST TR POT - Imperador Augusto Poder de Tribuno. No reverso, vemos um círculo linear, no campo da moeda. No

\footnotetext{
5 Todas moedas apresentadas nesse texto também integram ao Catálogo Iconográfico Numismático Augustano (CINA), o qual foi publicado no apêndice $M$ de nossa tese de doutorado. Desse modo, apresentaremos os números de entradas das moedas do CINA, em nossas descrições das imagens (CAMPOS, 2017, p. 294).
} 
centro do campo, uma coroa cívica com a legenda em seu interior: OB CIVIS SERVATOS - Por ter salvo os Cidadãos.

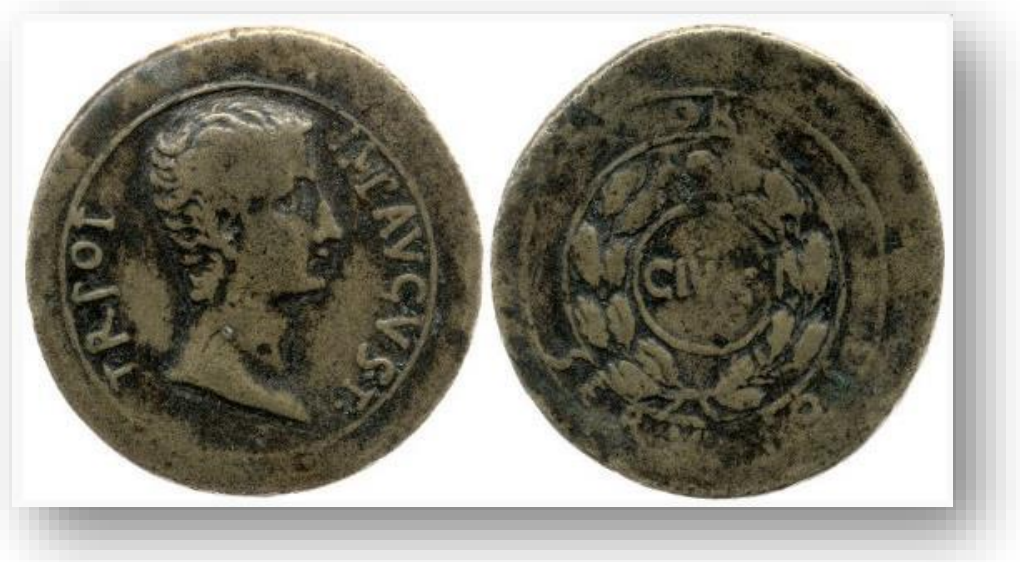

Fig. 2 Tipo de Moeda: Dupôndio- Bronze; Período: c.a 23 AEC; Região: Imprecisa- Prov. Península Itálica. Período - Principado de Augusto; CINA, apêndice M 123; Referência: RIC I 549.

No registro 323 no RIC I (fig. 3), temos outra moeda de sestércio, feita em bronze e com quatro recorrências do objeto, as mesmas cunhadas provavelmente em 18 AEC. No anverso da moeda, encontramos a coroa cívica no centro do campo e nas bordas laterais dois ramos de louro. Ainda no anverso é possível encontrar a legenda OB CIVIS SERVATOS - Por ter salvo os cidadãos. No reverso vemos a legenda em torno e no centro do campo S C - Por decreto do Senado. No entorno identificamos: Q AELIVS L F LAMIA IIIVIR A A A F F - Q. Aélio L. F. Lamia Triúnviro Áureo, Argento, Aere, Flando, Feriundo.
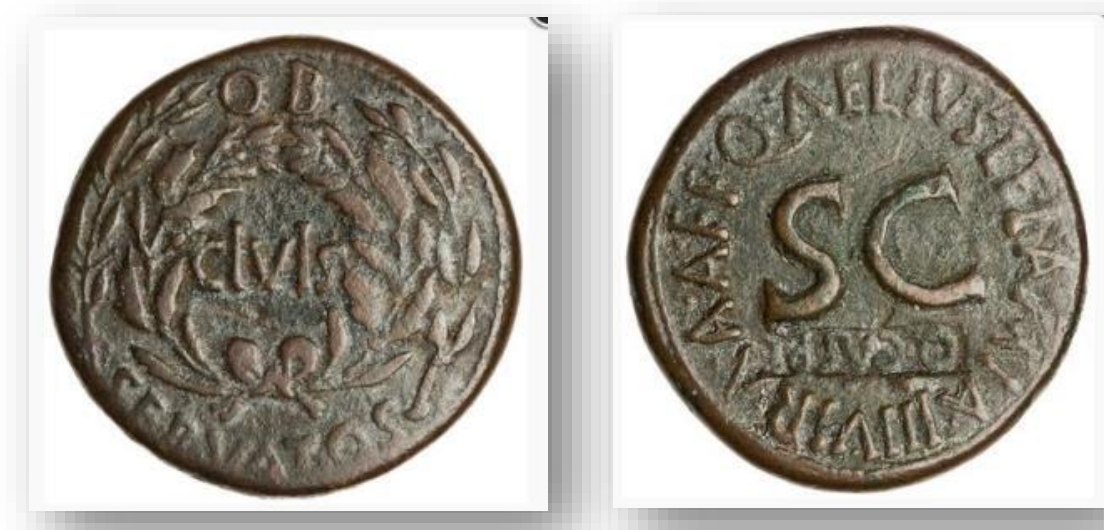

Fig. 3 Tipo de Moeda: Sestércio - Bronze; Período: c.a 18 AEC; Região: Península Itálica. Período Principado de Augusto; CINA, apêndice M 104; Referência: RIC I 323.

Acrescentamos em nossos estudos a moeda com registro 325 no RIC I (fig. 4), em que temos um sestércio, feito em bronze e com três recorrências do objeto, sendo que foram cunhadas provavelmente em $18 \mathrm{AEC}$, como no objeto anterior. No anverso da moeda, encontramos a coroa 
cívica no centro do campo e nas bordas laterais dois ramos de louro. Ainda no anverso é possível encontrar a legenda OB CIVIS SERVATOS - Por ter salvo os cidadãos. No reverso há legenda em torno e no centro do campo S C - Por decreto do Senado. No entorno, vemos: C MARCI L F CENSORIN AVG IIIVIR A A A F F - C. Marcio L. F. Censorino Augúrio Triúnviro Áureo, Argento, Aere, Flando, Feriundo.
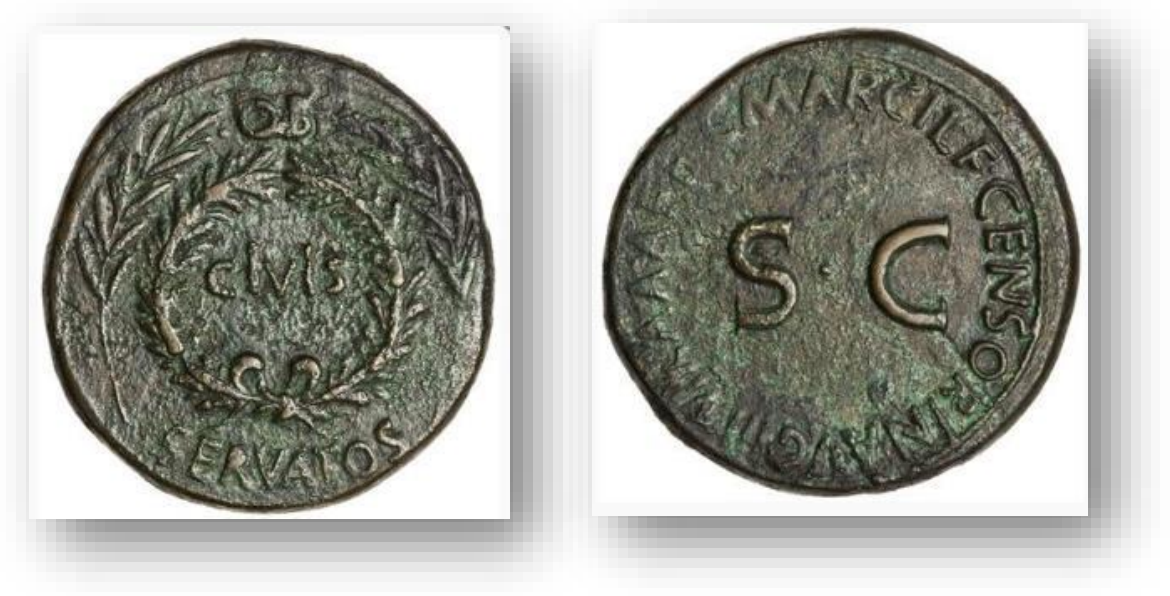

Fig. 4 Tipo de Moeda: Sestércio - Bronze; Período: c.a 18 AEC; Região: Península Itálica. Período Principado de Augusto; CINA: 106; Referência: RIC I 325.

Para finalizar, acrescentamos em nossos estudos a análise de uma moeda com registro 327 no RIC I (fig. 5), em que temos um sestércio, também feito em bronze e com duas recorrências do objeto. Vale salientar que tal moeda deve ter sido cunhada provavelmente em 18 AEC, como vimos nas demais catalogações. No anverso da moeda, encontramos a coroa cívica no centro do campo e nas bordas laterais dois ramos de louro. Ainda no anverso é possível encontrar a legenda OB CIVIS SERV ATOS - Por ter salvo os cidadãos. No reverso há legenda em torno e no centro do campo S C - Por decreto do Senado. No entorno, vemos: T QVINCTIVS CRISPINVS SVLPIC IIIVIR A A A F F - T. Quintio Crispino Sulpicio Triúnviro Áureo, Argento, Aere, Flando, Feriundo.
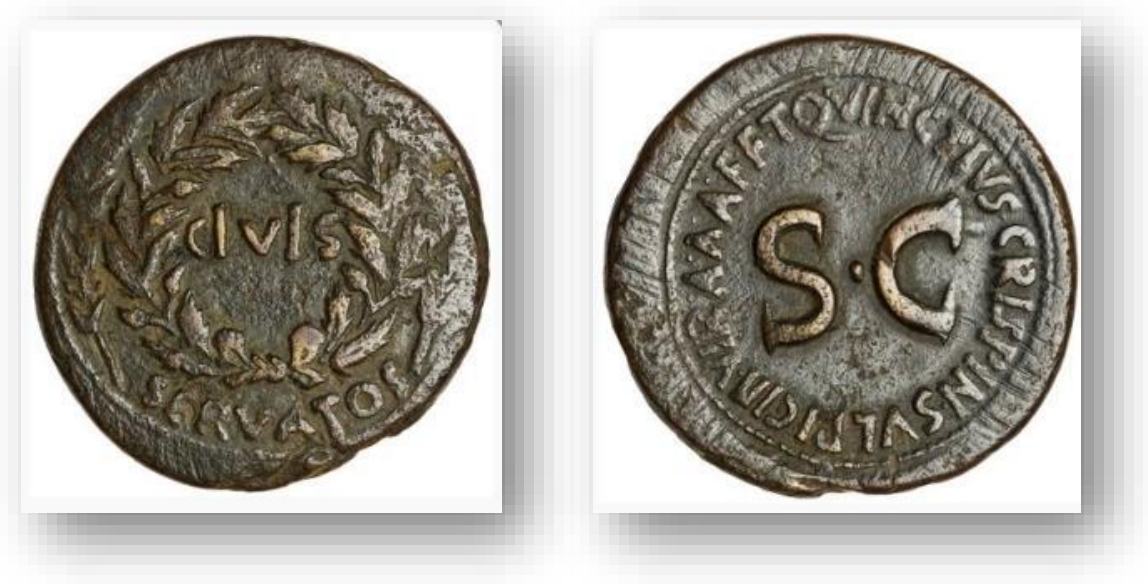

Fig. 5 Tipo de Moeda: Sestércio - Bronze; Período: c.a 18 AEC; Região: Península Itálica. Período Principado de Augusto; n.: 108; Referência: RIC I 327. 
Michael Crawford, Coinage and Money under the Roman Republic: Italy and the Mediterranean Economy (1985, p. 256-280), Christopher Howgego, em Ancient History from Coins (1995, p. 39-60) e David Sear, Roman coins and their values (2000, p. 17-26) endossam nossa perspectiva do uso do sestércio como uma das moedas que mais propagaram a imagem de Augusto entre 27 AEC-14 EC, por sua alta emissão a partir das reformas monetárias de Augusto, que foram promovidas na década de vinte. Facilitou a sua alta circulação entre os cidadãos e o seu valor de uso cotidiano. Com isso, ressaltamos que tal uso não se limitou à Península Itálica, mas também foi estendido pelas áreas provinciais, pelas trocas comerciais. No que tange ao áureo, por seu valor em ouro, o mesmo era uma moeda importante para o comércio, principalmente de produtos de alto valor, assim como para a captação de recursos e demonstração de poder. Desse modo, cunhar em áureo demonstrava o interesse de difusão política da sua imago principis, essencialmente entre os meios abastados, como foi mencionado por Christopher Howgego. Os receptores desses discursos podem ser pensados como amplos, visto que englobavam diversas regiões da Vrbs e das províncias. Assim, é notório que havia uma grande interação dos cidadãos e não-cidadãos com as moedas. Quanto à imagem e à linguagem, observamos que as moedas augustanas apresentam a transmissão de imagens referentes a símbolos cívicos que deviam propagar a imagem do princeps. A linguagem imagética na Península Itálica ratificava um programa político augustano de ordenador do mundo conhecido.

Diversos são os comentários que podemos tecer acerca de tais moedas. Tomando Howgego como nossa fundamentação teórico-metodológica, frisamos que o repertório de Augusto como o Salvador dos Cidadãos de Roma se insere no tema da legitimação do poder. Uma das preocupações dessa tônica está relacionada com as qualidades morais e as titulaturas assumidas, mediante aprovação da população. Tendo a como suporte, a linguagem monetária transmite ao receptor que tal governante está apto para o governo e assim manter a ordem social e cósmica do mundo romano.

O que as moedas podem evidenciar em uma perspectiva conjuntural de análise iconográfica?

O primeiro ponto que podemos destacar é a repetição da legenda do anverso que confere a Augusto o papel de Salvador dos Cidadãos, ou seja, propagando a ideia de auctoritas $^{6}$ augustana, para os cidadãos. Segundo Seth William Stevenson e Frederic Madden (1889, p. 582), em $A$ dictionary of roman coins, republican and imperial, a legenda OB CIVIS SERVATOS, era uma inscrição comendatória, a qual foi conferida para poucos homens na história da República Romana. Era uma atribuição que no imaginário social romano elevava um cidadão diante dos demais, como também percebemos nos textos de Michael Crawford, Christopher Howgego e David Sear. Do mesmo modo, notamos nas referidas moedas que estas também possuem a complementação S C, a qual indica Senatus Consultum. Tal legenda ratifica o discurso contido na moeda, isto é, de que foi produzida por meio da autoridade pública do Senado, de acordo com a Constituição da República, e as regras da casa da moeda em que ela foi produzida, como foi postulado por Stevenson e Madden (1889, p. 710).

O segundo ponto que elencamos diz respeito ao uso dos símbolos cívicos romanos que se entrelaçam com a concepção de salvador de Roma, ou seja, a coroa cívica e os ramos de louro. Iniciamos expondo que a coroa cívica pode ser pensada como uma guirlanda de carvalho. Durante

\footnotetext{
${ }^{6}$ Auctoritas: a capacidade de exercer poder sobre as pessoas e eventos por meio do status de alguém sem o uso da força ou violência física como condicionante, devido a reputação pessoal (CAMPOS, 2017, p. 381).
} 
a República Romana e no Principado, ela foi considerada como uma das mais altas condecorações militares que um cidadão poderia receber. Assim, foi reservada para comandantes que salvaram a vida dos concidadãos. Em 27 AEC, chegou a ser colocada na porta de Augusto, como ele argumenta nas Res Gestae. Mediante leituras de Howgego, apontamos que os ramos de louro são insígnias que, associadas ao OB CIVIS SERVATOS e à coroa cívica, conferem que o seu detentor era um cidadão vitorioso e foi capaz de salvar os romanos do caos. Com efeito, formava o repertório com os demais signos da moeda.

Outro dado que notamos nas moedas das figuras quatro, cinco e seis são os nomes dos magistrados Q. Aélio L. F. Lamia, C. Marcio L. F. Censorino Augúrio, T. Quintio Crispino Sulpicio. Tais homens integravam, no período de Augusto, o colégio dos tresuiri monetalis (tresviros/triúnviros monetários), os quais eram encarregados pela tradição republicana da amoedação e selecionados por uma eleição. Michael Crawford (1985, p. 25 - 51) sugere que durante a República os senadores controlavam as questões monetárias como o próprio colégio dos tresuiri monetaris. Entretanto, com a subida ao poder de Otávio Augusto, uma aparente "diarquia" parece ter sido formulada em Roma. O Senado passou a cuidar das taxas públicas sobre os metais que iriam ser cunhados. Enquanto a emissão de moedas de ouro e prata, no primeiro momento, foi colocada sob a tutela augustana. Contudo, H. Mattingly (1977) e Jonatham Williams (2007, p. 143 - 163) convergem que o Senado, na realidade, não teria mais esse poder de controle ou decisão em finais do século I AEC. Por isso, esses magistrados começaram a exercer as suas escolhas pessoais sobre os símbolos e personalidades que deveriam aparecer na cunhagem romana, principalmente, com base em temas referentes à sua gens, nas dos seus aliados e, posteriormente, do princeps. Assim, os indicados provavelmente se encontravam sobre influência direta ou indireta de Augusto, pois eram selecionados e/ou aprovados por ele.

Em suma, percebemos que a política augustana se relaciona com o impacto político decorrente dos confrontos bélicos no Ácio. Otávio Augusto, ao vencer seu maior rival, se propôs a formular um discurso de retomada da ordem social e, a partir de então, apesar da existência de alguns embates, eles ficavam fora dos principais centros políticos do império. A linguagem iconográfica representou Augusto como o responsável pelo estabelecimento da paz romana, assim promovendo a valorização de um grande feito, salvar os cidadãos do caos, no imaginário social de Roma. Esse era um processo que visava sustentar o poder augustano e corresponder as demandas sociais da população romana.

\section{Referência Documental Literária:}

CESAR AUGUSTO. Res Gestae (Coisas Feitas). Tradução: Matheus Trevizam, Paulo Sérgio Vasconcellos, Antônio Martinez Rezende. Belo Horizonte - Mg: Ed. UFMG, 2007.

Res Gestae Divi Augusti. Trad.: John Scheid. Paris: Belle Lettres, 2007.

\section{Referências de matriz arqueológica:}

EHRENBERG, Victor; JONES, A. H. M. Documents illustrating the reigns of Augustus \& Tiberius. Oxford: At the Clarendon Press, 1949.

RIC - Roman Imperial Coinage, Vol. 1, segunda edição. Por C. H. V. Sutherland e R. A. G. Carson, 
Londres - UK: Spike and Sons, 1984 (Primeira edição em 1923).

\section{Referências bibliográficas:}

BACZKO, B. (1985). A Imaginação Social. In: LEACH, Edmund (et alli). Anthropos-Homem. Lisboa, Imprensa Nacional/Casa da Moeda.

BÉRARD, C. (1983). Iconographie - Iconologie - Iconologique. In: Études de Lettres, v.4, Paris, p. $5-37$.

BÉRANGER, J. (1975). Principatus: études de notions et d' histoire politiques dans l' Antiquité gréco-romaine. Genova, Librairie Droz S. A.

BUSTAMANTE, R. M. C. (2006). Práticas Culturais no Império Romano: Entre Unidade e a Diversidade. In: SILVA, Gilvan Ventura da \& MENDES, Norma Musco (org.). Repensando o Império Romano - Perspectiva Socioeconômica, Política e Cultural. Rio de Janeiro, Mauad, Vitória - Es, EDUFES, p. $109-136$.

CACCAMO-CALTABIANO, M. (1998). II simbolismo del "Lepre". Influenze ideologico-religiose dell'Egitto sull'area dello Stretto riflesse dal documento monetale. In: BONACASA, N [et. ali]. L'Egitto in Italia dall'Antichità al Medioevo. Atti Congresso Internazionale - Roma-Pompei (1995), n: 13-19, Roma, nov., p. 33 - 40.

CAMPOS, C. E. C. (2017) Otávio Augusto e as suas redes político-religiosas nos quattuor amplissima collegia sacerdotum romanorum (29 AEC - 14 EC). Tese de Doutorado apresentada ao Programa de Pós-Graduação em História, da Universidade do Estado do Rio de Janeiro, Rio de Janeiro.

CRAWFORD, M. H. (1985). Coinage and Money under the Roman Republic: Italy and the Mediterranean Economy. California - USA, University of California Press, 1985.

CRAWFORD, M. H. (1974) Roman Republican Coinage.Vol.:Il.Cambridge - UK, Cambridge University Press.

DIAS, C. K. B. (2009). O pintor de Gela. Características formais e estilísticas, decorativas e iconográficas. Tese apresentada ao Programa de Pós-Graduação em Arqueologia, do Museu de Arqueologia e Etnologia, da Universidade de São Paulo, São Paulo.

FAVERSANI, F. (2013). Entre a República e o Império: apontamentos sobre a amplitude desta fronteira. Revista Mare Nostrum, n. 4, p. 100 - 11.

GALINSKY, K. (2012). Augustus - Introduction to the life of emperor. Cambridge, Cambridge University Press.

HOWGEGO, C. (1995). Ancient History from Coins. London - UK, Routledge.

KNOKE, D. (1990). Political Networks - the Structural Perspective. Cambridge, Cambridge University Press.

LISSARRAGUE, F. (1990). L'autre guerrier: Archers, peltastes, cavaliers dans l'imagerie atiique. Images à l'appui, $n^{\circ}$ 3. Paris-Rome, Editions La Découverte / Ecole française de Rome.

MATTINGLY, H. (1977). Roman coins: from the earliest times to the fall of the western empire. London, Taylor and Francis.

MEIER, C. (1993). Caesar Divi filius and the Formation of the Alternative in Rome. In: RAAFLAUB, Kurt A.; TOHER, Mark.; BOWERSOCK, G. W(org). Between Republic and Empire: Interpretations of 
Augustus and His Principate. California - USA, University of California Press, p. 54 - 70.

PORTO, V. C. (2007). Imagens Monetárias na Judeia / Palestina sob dominação romana. Tomo I: A moeda na Judeia/Palestina entres os séculos II a.C - II d.C.: Histórico e Análises. Tese de doutorado apresentada ao Programa de Pós-Graduação em Arqueologia, do Museu de Arqueologia e Etnologia, da Universidade de São Paulo, São Paulo.

SEAR, D. R. (2000), Roman coins and their values: The millennium edition. vol. I. London, Spink.

STEVENSON, S. W.; MADDEN, F. W. (1889). A dictionary of Roman coins, republican and imperial. London, G. Bell and Sons.

VERNANT, J. P. (1984). La cité des images. Paris, Nathan.

VEYNE, P. (2009). O Império Greco-Romano. Rio de Janeiro, Ed. Elsevier.

WALLACE-HADRILL, A. (2012). Augustan Rome. London, Bristol Classical Press.

WILLIAMS, J. (2007). Religion and Roman Coins. In: RUPKE, Jorg (org). A Companion to Roman Religion. Oxford - UK, Blackwell Publishing, p. $143-163$.

YAVETZ, Z. (1993). The Personality of Augustus: Reflections on Syme's Roman Revolution. In: RAAFLAUB, Kurt A.; TOHER, Mark.; BOWERSOCK, G. W(org). Between Republic and Empire: Interpretations of Augustus and His Principate. California - USA: University of California Press, p. 21 - 41.

ZANKER, P. (1992). Augusto y el poder de las imágenes. Madrid - ES, Alianza Editorial.

Artigo recebido em: 13/02/2019

Artigo aceito em: 29/05/2019 